\title{
Physical Modeling of Semi-continuous Casting for Developing an Industrial Technology of Producing Ingots From New Deformable Aluminum Alloys
}

\section{Aleksandr Innokentyevich Bezrukikh}

Siberian Federal University School of Non-Ferrous Metals and Material Science: Sibirskij federal'nyj universitet Institut cvetnyh metallov i materialovedenia

\section{Vladimir Nikolaevich Baranov}

Siberian Federal University School of Non-Ferrous Metals and Material Science: Sibirskij federal'nyj universitet Institut cvetnyh metallov i materialovedenia

\section{Igor Lazarevich Konstantinov}

Siberian Federal University School of Non-Ferrous Metals and Material Science: Sibirskij federal'nyj universitet Institut cvetnyh metallov i materialovedenia

\section{Pavel Olegovich Yuryev}

Siberian Federal University School of Non-Ferrous Metals and Material Science: Sibirskij federal'nyj universitet Institut cvetnyh metallov i materialovedenia

\section{Denis Sergeevich Voroshilov ( $\sim$ d.s.voroshilov@gmail.com )}

Siberian Federal University School of Non-Ferrous Metals and Material Science: Sibirskij federal'nyj universitet Institut cvetnyh metallov i materialovedenia https://orcid.org/0000-0002-1406-3665

\section{Tamara Aleksandrovna Orelkina}

Siberian Federal University School of Non-Ferrous Metals and Material Science: Sibirskij federal'nyj universitet Institut cvetnyh metallov i materialovedenia

\section{Dmitriy Nikolaevich Bondarenko}

Siberian Federal University School of Non-Ferrous Metals and Material Science: Sibirskij federal'nyj universitet Institut cvetnyh metallov i materialovedenia

\section{Evgeniy Gennadyevich Partyko}

Siberian Federal University School of Non-Ferrous Metals and Material Science: Sibirskij federal'nyj universitet Institut cvetnyh metallov i materialovedenia

\section{Valentin Viktorovich Yanov}

Siberian Federal University School of Non-Ferrous Metals and Material Science: Sibirskij federal'nyj universitet Institut cvetnyh metallov i materialovedenia

\section{Nikita Andreevich Stepanenko}

Siberian Federal University School of Non-Ferrous Metals and Material Science: Sibirskij federal'nyj universitet Institut cvetnyh metallov i materialovedenia

\section{Yuriy Viktorovich Baykovskiy}

Siberian Federal University School of Non-Ferrous Metals and Material Science: Sibirskij federal'nyj universitet Institut cvetnyh metallov i materialovedenia 
Siberian Federal University School of Non-Ferrous Metals and Material Science: Sibirskij federal'nyj universitet Institut cvetnyh metallov i materialovedenia

\section{Yulbarskhon Nabievich Mansurov}

Siberian Federal University School of Non-Ferrous Metals and Material Science: Sibirskij federal'nyj universitet Institut cvetnyh metallov i materialovedenia

\section{Research Article}

Keywords: Casting of aluminum alloys, Rolling, Mechanical properties, Scandium, Aluminum-magnesium alloys, Heat treatment

Posted Date: October 5th, 2021

DOI: https://doi.org/10.21203/rs.3.rs-945415/v1

License: (c) (7) This work is licensed under a Creative Commons Attribution 4.0 International License. Read Full License 


\section{Abstract}

A physical model of a semi-continuous casting unit (SCCU) has been manufactured and tested, designed to develop a technology for casting flat and cylindrical ingots from experimental aluminum alloys for subsequent metal forming. The SCCU includes two induction melting furnaces with a tilting mechanism, a rotary mixer, a metal path system, a vertical casting machine, a jib crane, water supply, power supply, monitoring and control systems. SCCU testing was carried out on six heats of alloy 1580 of the Al-Mg system with the addition of scandium. In the first three ingots the scandium content was $0.05 \%$ (wt.). In the second series of three heats ingots with $0.075 \%$ (wt.) scandium were cast. The ingots had a high surface quality, did not have casting defects, and there were no inclusions of primary intermetallic compounds $\mathrm{Al}_{3}(\mathrm{Sc}, \mathrm{Zr})$ in the structure of the ingots. The bottom and runner parts of the ingots were cut off, all faces were milled and subjected to homogenization annealing in a two-stage mode: the first heating at $350^{\circ} \mathrm{C}, 3 \mathrm{~h}$, the second heating for $1 \mathrm{~h}$ to $425^{\circ} \mathrm{C}, 4 \mathrm{~h}$. Then the billets were hot rolled from 40 to $5 \mathrm{~mm}$, annealed at $380^{\circ} \mathrm{C}, 1 \mathrm{~h}$, rolled at room temperature to a thickness of $1 \mathrm{~mm}$ and annealed at $350^{\circ} \mathrm{C}, 3 \mathrm{~h}$. After that, tensile mechanical properties were tested. The results of modeling ingot casting were tested in industrial conditions when casting a large ingot with a cross section of $2100 \times 500 \mathrm{~mm}$. A template was cut from the ingot with the dimensions of a billet for rolling, as that obtained from an experimental ingot cast at the SCCU. The billet was subjected to hot and cold rolling according to the conditions used for rolling the experimental ingot. At the same time the modes of heat treatment of sheet semi-finished products were also repeated. The mechanical properties of sheets of alloy 1580 rolled from experimental and industrial ingots practically did not differ. This proves the reliability of casting modes for ingots obtained at the SCCU and tested for casting industrial ingots.

\section{Introduction}

Alloys of the Al-Mg system have significant advantages, such as satisfactory strength, high corrosion resistance, and good weldability [1-9]. Despite the fact that these alloys are not subject to hardening due to heat treatment [10-17], they are widely used in various industries, such as rocketry, aviation, shipbuilding and automotive [18-25]. The most promising alloys for use in these high-tech industries are Al-Mg alloys with additions of scandium $(1515,1523,1545,1545 \mathrm{~K}, 1570,1570 \mathrm{C})$, to which many works are devoted [4-6, 22, 2530]. Despite the huge potential of the Al-Mg-Sc system alloys developed in industry, scandium remains very expensive and rather difficult to obtain metal [31-33]. Therefore, research by various scientists around the world is aimed at studying the possibility of reducing the amount of scandium in aluminum alloys $[34,35]$.

The main method for producing large-sized ingots from aluminum alloys for the subsequent production of semi-finished products by metal forming is semi-continuous casting [27]. At the stage of mastering the technology for producing ingots from new alloys, knowledge of the optimal casting modes is required. The most accurate casting parameters can be given by experiments using industrial equipment designed for the production of these products. However, studies carried out in the conditions of existing production have the following disadvantages:

- - the need to withdraw industrial equipment and maintenance personnel from the current production process for the duration of the experiments;

- - high energy and material costs; 
- - the impossibility or high cost of varying the investigated process parameters in wide ranges;

- - the likelihood of an accident and failure of production equipment, etc.

The most promising way out of this situation is modeling, which allows experiments to be carried out under laboratory conditions. This approach makes it possible to find acceptable boundaries for changing technological parameters, or to establish a range of parameters that would lead to the achievement of the best ratio of research costs and profit obtained from the introduction of new technology.

It is believed that of all types of modeling for the development of modes of semi-continuous casting of ingots from aluminum alloys, physical modeling is the most relevant. Therefore, the purpose of this work was to develop and test a physical model of a semi-continuous casting unit (SCCU) for aluminum alloys. To achieve this goal, the following tasks were solved in the work:

- - creation of a physical model of the SCCU;

- - conducting experimental testing of the casting modes of a new aluminum alloy at the SCCU;

- - study of the structure and properties of semi-finished products obtained at the SCCU;

- - study of manufacturability during metal forming of ingots manufactured at the SCCU;

- - testing the obtained experimental modes of modeling in industrial conditions.

\section{Method Of Carrying Out Research}

The physical model of the unit for semi-continuous casting of aluminum alloys was designed and manufactured with the support of the Ministry of Higher Education and Science of the Russian Federation, RUSAL Bratsk and the Russian Foundation for Basic Research (RFBR) at the Siberian Federal University (SFU) in 2020 [27]. The purpose of the SCCU is the development and testing of technologies for casting flat or cylindrical ingots from standard or new aluminum alloys intended for subsequent metal forming. The general view of the SCCU is shown in Fig. 1.

The SCCU includes two induction melting furnaces with a hydraulic tilt mechanism, an electrically heated rotary mixer, a metal track system, a vertical casting machine, a cantilever crane, water supply, power supply, monitoring and control systems. The main equipment and tooling of the SCCU are mounted on a frame, which is a steel frame structure.

The work of the SCCU is organized as follows (Fig. 2). In induction crucible furnaces 1, the charge is melted to prepare an alloy of a given chemical composition. Then the melt is poured through the metal track 2 into a rotary electrically heated mixer 3 , in which it is subjected to settling, modification and refining with argon. After that, due to the tilt of the mixer, the melt with a predetermined temperature is fed through the metal path to the filtration section, which is a chamber 4 with a ceramic foam filter. Further, the molten metal enters the vertical casting machine 5, which, with the given casting parameters, forms an ingot in the mold 6 . The section of the ingot can be round in diameter up to $190 \mathrm{~mm}$ or rectangular in size $60 \times 200 \mathrm{~mm}$. The complex also includes a cantilever crane designed to service the main equipment.

1 - induction crucible furnaces; 2 - metal track with heated lid; 3 - rotary electrically heated mixer; 4 - filtration section; 5 - vertical casting machine; 6 - mold 
The main technical characteristics of the SCCU are given in Table 1.

Table 1

- Main technical characteristics of SCCU units

\begin{tabular}{|c|c|}
\hline Unit of SCCU name & Main characteristics \\
\hline $\begin{array}{l}\text { Low frequency induction furnace IAT-0.16 (2 } \\
\text { pcs) }\end{array}$ & $\begin{array}{l}\text { - maximum temperature } 1050^{\circ} \mathrm{C} \text {; } \\
\text { - capacity of one furnace no more than } 55 \mathrm{~kg} \text { (for } \\
\text { aluminum); } \\
\text { - weight of one furnace no more than } 1000 \mathrm{~kg} \text {; } \\
\text { - power per one furnace } 80 \mathrm{~kW} \text {; } \\
\text { - argon degassing mechanism. }\end{array}$ \\
\hline Transport chute system - metal track & $\begin{array}{l}\text { - casting troughs with the possibility of heating before } \\
\text { casting. }\end{array}$ \\
\hline Rotary electrically heated mixer & $\begin{array}{l}\text { - maximum temperature } 850^{\circ} \mathrm{C} \text {; } \\
\text { - capacity not more than } 160 \mathrm{~kg} \text { (for aluminum); } \\
\text { - weight no more than } 700 \mathrm{~kg} ; \\
\text { - power up to } 30 \mathrm{~kW} \text {; } \\
\text { - argon degassing mechanism. }\end{array}$ \\
\hline Filtration section & $\begin{array}{l}\text { - the ability to filter the melt; } \\
\text { - complete heating system for filtration plant. }\end{array}$ \\
\hline Vertical casting machine & $\begin{array}{l}\text { - casting speed from } 1 \text { to } 250 \mathrm{~mm} / \mathrm{min} \text {; } \\
\text { - ingot length up to } 1100 \mathrm{~mm} \text {; } \\
\text { - ingot weight no more than } 100 \mathrm{~kg} \text {; } \\
\text { - drive power } 2 \mathrm{~kW} \text {; }\end{array}$ \\
\hline Molds & $\begin{array}{l}\text { - section of the obtained ingots: } 60 \times 200,80 \times 180, \emptyset 190 \\
\text { mm; } \\
\text { - coolant volume from } 0.1 \text { to } 15 \mathrm{~m}^{3} ; \\
\text { - type of lubricant: oil, lubricants, etc. }\end{array}$ \\
\hline
\end{tabular}

The SCCU is controlled from the local operator panel, on which the main parameters of the casting, entering the database, are set and controlled. The database provides for their issuance in a format convenient for loading into computer programs, which will allow simulating various casting modes.

To test the operation of the SCCU a new Russian alloy 1580 of the Al-Mg system was used with the addition of scandium, which was studied in [27, 28, 36-50]. The mechanical properties of the obtained deformed semifinished products were studied in [27, 39-48]. Also, computer simulation was carried out to study the modes of rolling of a new alloy [36-39]. The modes of sheet annealing were investigated [45, 48-50], as well as the 
properties of welded joints from alloy $1580[48,49]$. Corrosion properties were studied in $[48,50]$. In this alloy the scandium content should be $0.05-0.14 \%$ (wt.). To reduce the content of expensive scandium in the alloy, its concentration should be taken closer to the lower limit of the allowable range in the alloy grade. During testing six heats were carried out. In the first three heats, the task was to obtain ingots with scandium content close to the lower limit of the specified interval $-0.05 \%$ (wt.). In the second series of three heats it was necessary to obtain alloys with a scandium content of $0.075 \%$ (wt.). This corresponds to the middle of the interval of this element in the alloy grade. Alloys were prepared in an IAT-0.16 induction furnace in an amount of $50 \pm 0.1 \mathrm{~kg}$ using A85 grade aluminum. The analysis of alloys for compliance with the planned chemical composition was carried out on an optical emission spectrometer "Foundry master lab". Upon reaching the required chemical composition, the resulting alloys were poured from the furnace into a rotary mixer, held, and then the Al-5Ti-1B master alloy was added.

Alloy 1580 is mainly used for the production of sheets of different thicknesses [27, 37-39, 42, 43, 45-48]; therefore, the alloy was poured from a rotary mixer into the mold of a casting machine with a rectangular cross section of $60 \times 200 \mathrm{~mm}$ in order to use an ingot for sheet rolling. The tilt speed of the mixer was synchronized with the casting speed of the ingot and the level of metal in the mold. All ingots were cast at the same temperature and speed parameters. The temperature of the alloys was: in an induction furnace $800 \pm 8^{\circ} \mathrm{C}$; in the mixer $750 \pm 5^{\circ} \mathrm{C}$, on the mold of the casting machine $700-705^{\circ} \mathrm{C}$. The chemical composition of the alloys is given in Table 2.

Table 2

- Chemical composition of alloys for testing SCCU

\begin{tabular}{|lllllll|}
\hline Alloy number & \multicolumn{7}{l}{ Mass fraction of elements, \% } & \\
\cline { 2 - 7 } & Sc & Fe & Mn & Mg & The sum of other & Al \\
\hline 1 & 0.055 & 0.19 & 0.52 & 4.98 & 0.30 & basis \\
\hline 2 & 0.054 & 0.17 & 0.52 & 5.01 & 0.35 & basis \\
\hline 4 & 0.053 & 0.17 & 0.62 & 5.21 & 0.32 & basis \\
\hline 5 & 0.077 & 0.20 & 0.61 & 5.16 & 0.30 & basis \\
\hline 6 & 0.075 & 0.22 & 0.51 & 5.42 & 0.32 & basis \\
\hline
\end{tabular}

Preparation of ingots for rolling included cutting the bottom and gating parts (at least $100 \mathrm{~mm}$ ), milling all edges to a depth of 2-3 $\mathrm{mm}$, and homogenizing annealing. The annealing regime was carried out according to a two-stage regime: the first heating at $350^{\circ} \mathrm{C}$ and holding for $3 \mathrm{~h}$, the second heating for $1 \mathrm{~h}$ to $425^{\circ} \mathrm{C}$ and holding for $4 \mathrm{~h}$ [47]. The view of the ingot prepared for rolling is shown in Fig. 3.

Hot rolling was carried out in the laboratory of the Department of Metal Forming of the Siberian federal university on a two-roll mill with a roll diameter of $330 \mathrm{~mm}$ and a barrel length of $520 \mathrm{~mm}$. To carry out hot rolling ingots with dimensions of $40 \times 120 \times 170 \mathrm{~mm}$ were heated to $450^{\circ} \mathrm{C}$ and rolled in the casting direction to a thickness of $5 \mathrm{~mm}$ with single reductions of $5-10 \%$. The total rolling reduction was $88 \%$. Then the sheets were annealed at $380^{\circ} \mathrm{C}$ for $1 \mathrm{~h}$. After that, the hot-rolled sheets were rolled at room temperature on a two-roll mill with 
a roll diameter of $200 \mathrm{~mm}$ and a barrel length of $400 \mathrm{~mm}$, brand LS 400 AUTO manufactured by Mario Di Maio (Italy) to a thickness of $1 \mathrm{~mm}$ with single reductions of $2-5 \%$. The total reduction rate was $80 \%$. Cold-rolled sheets were annealed at $350^{\circ} \mathrm{C}$ for $3 \mathrm{~h}$, and samples were cut from them for research.

The microstructure of the alloys was analyzed using an Observer A1 $\mathrm{m}$ light microscope, Carl Zeiss. The processes of recrystallization of alloys were studied in the polarized light mode after deposition of an oxide film on the samples.

The mechanical properties of hot and cold rolled sheets were determined by tensile tests at room temperature on a Walter + BaiAG LFM 400 kN universal testing machine in accordance with State Standard 1497-84.

\section{Results And Discussion}

At external examination the ingots of alloy 1580 obtained at the SCCU were characterized by a high surface quality. Foundry equipment and general view of the ingot are shown in Fig. 4.

After cutting the bottom and gating parts of the ingots, as well as after milling all surfaces of the ingots, no casting defects in the form of cavities and inclusions were found, which indicates the correct selection of technology.

The microstructure of cast ingots, which was carried out before and after homogenization annealing is shown in Fig. 5.

On the microstructure of alloy No.1 with a Sc content of $0.055 \%$ (wt.) in the cast state, there is grains of an asolid solution with chemical inhomogeneity over the cross section of dendritic cells (Fig. 5a). Along the boundaries of the cells, inclusions of the nonequilibrium phase $\beta\left(\mathrm{Al}_{8} \mathrm{Mg}_{5}\right)$, the $\mathrm{Mg}_{2}$ Si phase, and a large number of phases containing iron $\mathrm{Al}_{6}(\mathrm{Fe}, \mathrm{Mn})$ and $\mathrm{Al}_{15}(\mathrm{Fe}, \mathrm{Mn})_{3} \mathrm{Si}_{2}$ were also found. In this case, the structure of the ingots did not contain inclusions of primary intermetallic compounds $\mathrm{Al}_{3}(\mathrm{Sc}, \mathrm{Zr})$ [47]. Consequently, scandium and zirconium in the alloy were only in a supersaturated solid solution and the cooling mode during casting was chosen correctly.

In the two-stage annealing of ingots, according to [21], two processes occur: homogenization and heterogenization of the structure. For this alloy, upon homogenization, the dissolution of the nonequilibrium phase $\beta\left(\mathrm{Al}_{8} \mathrm{Mg}_{5}\right)$, partly of the $\mathrm{Mg}_{2}$ Si phase, and elimination of chemical inhomogeneity over the cross section of the dendritic cell and grain occurred. Heterogenization of the alloy led to the decomposition of the aluminum solid solution supersaturated with respect to $\mathrm{Sc}, \mathrm{Zr}, \mathrm{Mn}$ with the release of dispersed particles $\mathrm{Al}_{3}(\mathrm{Sc}, \mathrm{Zr})$ and $\mathrm{Al}_{6} \mathrm{Mn}$ and proceeded in two stages. At the first stage, at $350^{\circ} \mathrm{C}$, a homogeneous decomposition of a solid solution of scandium and zirconium occurred with the formation of particles of a stable coherent $\mathrm{Al}_{3}(\mathrm{Sc}, \mathrm{Zr})$ phase several nanometers in size and with a high distribution density. At the second stage of annealing at a temperature of $425^{\circ} \mathrm{C}$, the decomposition was completed with a small coarsening of dispersed particles of the hardening phase $\mathrm{Al}_{3}(\mathrm{Sc}, \mathrm{Zr})$. Also at this stage, the manganese solid solution decomposed with the formation of secondary precipitates. 
The microstructure of alloy No.1 in the annealed state (Fig. $5 b$ ) practically did not differ from the cast structure, and insignificant differences in the microstructure can be explained by dissolution during annealing of the nonequilibrium $\beta\left(\mathrm{Al}_{8} \mathrm{Mg}_{5}\right)$ phase and partial dissolution of the $\mathrm{Mg}_{2} \mathrm{Si}$ phase.

Analysis of the microstructure of alloys in polarized light showed (Fig. $5 c, d)$ that the grain size of the alloys in the annealed state practically does not change in comparison with the cast state. Studies of the microstructure of the ingot of alloy No.5, containing $0.75 \%$ (wt.) Sc, did not reveal any noticeable differences from the microstructure of the ingot of alloy No.1.

The average values of the results of testing the mechanical properties of tensile samples cut from hot-rolled and annealed sheets are given in Table 3. Analysis of these data showed that alloys Nos. 1-3 with a scandium concentration of $0.055 \%$ (wt.) Are similar in their properties. Alloys Nos. 4-6 containing 0.075 have a higher level of strength properties, especially in terms of yield strength $R_{p}$, which can be explained by a higher content of scandium. At the same time, the ductility of all six alloys is at the same level.

Table 3 - Mechanical tensile properties of hot-rolled sheet semi-finished products $5 \mathrm{~mm}$ thick after annealing at $380^{\circ} \mathrm{C}$ for $1 \mathrm{~h}$

\begin{tabular}{lllllllll} 
Alloy number & Sc, \% (wt.) & \multicolumn{3}{l}{ Mechanical properties } \\
\cline { 3 - 8 } & & \multicolumn{2}{l}{ Longitudinal direction } & \multicolumn{3}{l}{ Cross direction } \\
\cline { 3 - 8 } & & $R_{m}, \mathrm{MPa}$ & $R_{p}, \mathrm{MPa}$ & $A, \%$ & $R_{m}, \mathrm{MPa}$ & $R_{p}, \mathrm{MPa}$ & $A, \%$ \\
\hline 1 & 0.055 & 343 & 214 & 17 & 344 & 216 & 20 \\
\hline 2 & 0.054 & 338 & 213 & 19 & 338 & 212 & 18 \\
\hline 3 & 0.053 & 345 & 216 & 20 & 350 & 219 & 19 \\
\hline 4 & 0.077 & 366 & 244 & 16 & 368 & 244 & 18 \\
\hline 5 & 0.075 & 364 & 249 & 17 & 364 & 237 & 18 \\
\hline 6 & 0.075 & 365 & 241 & 18 & 367 & 243 & 17
\end{tabular}

The average values of the results of testing the mechanical properties of tensile samples cut from cold-rolled and annealed sheets are given in Table 4.

Table 4 - Tensile properties of cold-rolled sheet semi-finished products $1 \mathrm{~mm}$ thick after annealing at $350^{\circ} \mathrm{C}$ for $3 \mathrm{~h}$ 
Alloy number Sc, \% (wt.) Mechanical properties

\begin{tabular}{llllllll} 
& & \multicolumn{3}{c}{ Longitudinal direction } & \multicolumn{4}{c}{ Cross direction } \\
\cline { 3 - 8 } & & $R_{m}, \mathrm{MPa}$ & $R_{p}, \mathrm{MPa}$ & $A, \%$ & $R_{m}, \mathrm{MPa}$ & $R_{p}, \mathrm{MPa}$ & $A, \%$ \\
\hline 1 & 0.055 & 356 & 219 & 15 & 365 & 232 & 16 \\
\hline 2 & 0.054 & 362 & 234 & 14 & 363 & 242 & 18 \\
\hline 3 & 0.053 & 359 & 224 & 15 & 368 & 230 & 20 \\
\hline 4 & 0.077 & 406 & 295 & 12 & 408 & 302 & 13 \\
\hline 5 & 0.075 & 393 & 287 & 14 & 384 & 286 & 11 \\
\hline 6 & 0.075 & 403 & 305 & 12 & 401 & 301 & 11
\end{tabular}

The analysis of these data showed that in alloys Nos. 4-6 the level of strength properties exceeds the level of alloys Nos. $1-3$ by approximately $10-12 \%$. But at the same time the plasticity of alloys Nos. 1-3 in the transverse direction significantly exceeds the plasticity of alloys Nos. 4-6.

The results of modeling the casting of ingots from alloy 1580 were tested in the industrial conditions of a Russian metallurgical enterprise when casting a large ingot with a cross section of $2100 \times 500 \mathrm{~mm}$. The aim was to obtain an ingot in which the scandium content, as in the experimental ingots, should be in the range from 0.05 to $0.075 \%$ (wt.). A general view of the industrial casting tooling and the large-sized ingot obtained on it is shown in Fig. 6.

The chemical composition of a large ingot made of alloy 1580 is presented in Table 5.

Table 5 - The chemical composition of a large-sized industrial ingot made of alloy 1580

\begin{tabular}{llllll}
\multicolumn{5}{l}{ Mass fraction of elements, \% } \\
Sc & $\mathrm{Fe}$ & $\mathrm{Mn}$ & $\mathrm{Mg}$ & The sum of other & $\mathrm{Al}$ \\
\hline 0.067 & 0.25 & 0.51 & 5.10 & 0.30 & basis
\end{tabular}

From Table 6 it follows that the casting modes obtained during physical modeling at the SCCU, which were recommended for industrial testing, ensured the production of a large-sized ingot with a given scandium content. Upon external examination of the ingot and after its milling to a depth of 5-10 mm, defects of casting origin were not detected, and in the study of the microstructure, the precipitation of primary intermetallic compounds $\mathrm{Al}_{3}(\mathrm{Sc}, \mathrm{Zr})$ was not detected. From the ingot subjected to homogenization annealing under industrial conditions, a template was cut with a thickness of $40 \mathrm{~mm}$ and dimensions in plain view of 120×170 $\mathrm{mm}$, which repeated the dimensions of a billet for rolling, obtained from an ingot cast at the SCCU. The ingot was subjected to hot and cold rolling on the equipment of the laboratory of the Department of Metal Forming of the Siberian federal university according to the modes used for rolling experimental ingots. At the same time, the modes of heat treatment of sheet semi-finished products were also repeated. The mechanical properties of 1580 alloy sheets rolled from an industrial ingot are presented in Table 6. 
Table 6 - Mechanical tensile properties of semi-finished sheet products obtained by rolling a template cut from a large-sized ingot 1580, casted under industrial conditions

Billet characteristics

Mechanical properties

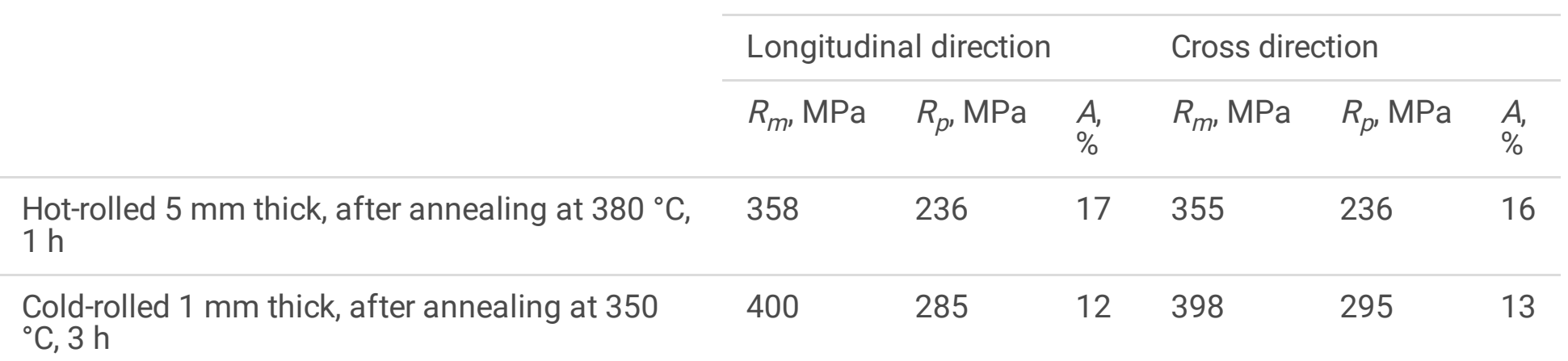

Comparison of the data given in Table 3, 4 and 6, allows concluding that the tensile properties of experimental and industrial ingots are approximately between the level of properties of alloys Nos. 1-3 and alloys Nos. 4-6, which corresponds to the average content of scandium in the industrial ingot between these groups of experimental alloys.

\section{Summary}

The studies carried out allowed concluding the following. The use of physical modeling of the process of semicontinuous casting of aluminum alloys on the SCCU experimental installation makes it possible to develop casting modes for new alloys. Industrial testing of the casting modes of ingots from the new alloy 1580, obtained at the SCCU, showed that the structure, as well as the mechanical properties of sheet semi-finished products from experimental and industrial large-sized ingots, practically did not differ. This proves the reliability of the modes of casting ingots obtained at the SCCU and the validity of their application to the industrial conditions of semi-continuous casting of ingots from aluminum alloys.

\section{Declarations}

\section{Ethical Approval}

The work contains no libelous or unlawful statements, does not infringe on the rights of others, or contain material or instructions that might cause harm or injury.

\section{Consent to Participate}

The authors consent to participate.

\section{Consent to Publish}

The authors consent to publish.

\section{Authors Contributions}

The authors declare that they are all participants in the work and none of them performed only administrative functions. 


\section{Funding}

The research was carried out within the framework of the state assignment of the Ministry of Science and Higher Education of the Russian Federation (scientific theme code FSRZ-2020-0011).

Use of equipment of Krasnoyarsk Regional Center of Research Equipment of Federal Research Center «Krasnoyarsk Science Center SB RAS» is acknowledged.

\section{Competing Interests}

The authors declare about the absence of competing interests.

\section{Availability of data and materials}

Not applicable.

\section{References}

1. Dong Q, Howells A, Lloyd DJ, Gallerneault M, Fallah V (2020) Effect of solidification cooling rate on kinetics of continuous/discontinuous $\mathrm{Al}_{3}(\mathrm{Sc}, \mathrm{Zr})$ precipitation and the subsequent age-hardening response in coldrolled AlMgSc(Zr) sheets. Mat Science and Eng A 772: 138693.

DOI: https://doi.org/10.1016/j.msea.2019.138693 Accessed 27 Sep 2021

2. Mengjia Li, Qinglin Pan, Yunjia Shi, Xue Sun, Hao Xiang (2017) High strain rate superplasticity in an AlMg-Sc-Zr alloy processed via simple rolling. Mat Science \& Eng A687: 298-305.

DOI: https://doi.org/10.1016/j.msea.2017.01.091 Accessed 27 Sep 2021

3. Weigui Zhang, Yanmiao Wu, Hongyu Lu, Guanqing Lao, Ke Wang, Yicong Ye, Peijie Li (2020) Discontinuous Precipitation of Nano-Al ${ }_{3} \mathrm{Sc}$ Particles in Al-Sc Alloy and Its Effect on Mechanical Property. Int J Nanoscience 19(1): 1850047. DOI: https://doi.org/10.1142/S0219581X18500473 Accessed 27 Sep 2021

4. Filatov YuA, Plotnikov AD (2011) Structure and properties of deformed semi-finished products from aluminum alloy $01570 \mathrm{C}$ of the $\mathrm{Al}-\mathrm{Mg}-\mathrm{Sc}$ system for the RSC "Energia” product. Tekhnologiya legkikh splavov [Light alloy technology] 2: 15-26.

5. Zakharov VV, Rostova TD (2014) Hardening of aluminum alloys due to scandium alloying. Met Sc Heat Treat 55(11-12): 660-664. DOI: https://doi.org/10.1007/s11041-014-9686-0 Accessed 27 Sep 2021

6. Zakharov VV, Fisenko IA (2019) Some Principles of Alloying of Aluminum Alloys with Scandium and Zirconium in Ingot Production of Deformed Semiproducts. Met Sc Heat Treat 61(3-4): 217-221. DOI: https://link.springer.com/article/10.1007\%2Fs11041-019-00403-4 Accessed 27 Sep 2021

7. Mondol S, Alamb T, Banerjee R, Kumar S, Chattopadhyay K (2017) Development of a high temperature high strength Al alloy by addition of small amounts of Sc and Mg to 2219 alloy. Mat Sci \& Eng A687: 221-231. DOI: https://doi.org/10.1016/j.msea.2017.01.037 Accessed 27 Sep 2021

8. Buranova Yu, Kulitskiy V, Peterlechner M, Mogucheva A, Kaibyshev R, Divinski SV, Wilde G (2017) $\mathrm{Al}_{3}(\mathrm{Sc}, \mathrm{Zr})$ based precipitates in Al-Mg alloy: Effect of severe deformation. Act Mater 124: 210-224.

DOI: https://doi.org/10.1016/j.actamat.2016.10.064 Accessed 27 Sep 2021 
9. Pedro Henrique R. Pereiraa, Ying Chun Wang, Yi Huang, Terence G. Langdon (2017) Influence of grain size on the flow properties of an Al-Mg-Sc alloy over seven orders of magnitude of strain rate. Mat Sc \& Eng A685: 367-376.

DOI: https://doi.org/10.1016/j.msea.2017.01.020 https://doi.org/10.1016/j.actamat.2016.10.064 Accessed 27 Sep 2021

10. Koryagin YuD, Il'in SI (2017) Recrystallization features of deformable aluminium-magnesium alloys with scandium. Bulletin of the South Ural State University. Series “Metallurgy" 17(1): 65-72.

11. Keith E. Knipling, David N. Seidman, David C. Dunand, (2011) Ambient- and high-temperature mechanical properties of isochronally aged $\mathrm{Al}-0.06 \mathrm{Sc}, \mathrm{Al}-0.06 \mathrm{Zr}$ and $\mathrm{Al}-0.06 \mathrm{Sc}-0.06 \mathrm{Zr}$ (at.\%) alloys. Act Mater 59: 943-954. DOI: https://doi.org/10.1016/j.actamat.2010.10.017 Accessed 27 Sep 2021

12. Xie J, Chen XP, Mei L, Huang GJ, Liu Q (2021) Investigation of the hardening behavior during recrystallization annealing in Al-Mg-Sc alloy. J All Comp 859: 157807.

DOI: https://doi.org/10.1016/j.jallcom.2020.157807 Accessed 27 Sep 2021

13. Jiang J, Jiang F, Zhang M, Tang Z, Tong M (2020) Effect of continuity of annealing time on the recrystallization behavior of Al-Mg-Mn-Sc-Zr alloy. Mat Lett 275: 128208.

DOI: https://doi.org/10.1016/j.matlet.2020.128208 Accessed 27 Sep 2021

14. Jiang J, Jiang F, Zhang M, Tang Z, Tong M (2020) $\mathrm{Al}_{3}(\mathrm{Sc}$, Zr) precipitation in deformed Al-Mg-Mn-Sc-Zr alloy: Effect of annealing temperature and dislocation density. J All Comp 831: 154856.

DOI: https://doi.org/10.1016/j.jallcom.2020.154856 Accessed 27 Sep 2021

15. Vlach M, Stulíková I, Smola B, Zaludová N, Cerná J (2010) Phase transformations in isochronally annealed mould-cast and cold-rolled Al-Sc-Zr-based alloy J All Comp 149: 243-148.

DOI: https://doi.org/10.1016/j.jallcom.2009.11.126 Accessed 27 Sep 2021

16. Jiang J, Jiang F, Zhang M, Tang Z, Tong M (2020) Recrystallization behavior of Al-Mg-Mn-Sc-Zr alloy based on two different deformation ways. Materials Letters 265: 127455.

DOI: https://doi.org/10.1016/j.matlet.2020.127455 Accessed 27 Sep 2021

17. Sun Y, Pan Q, Luo Y, Liu S, Wang W, Ye J, Shi Y, Huang Z, Xiang S, Liu Y (2021) The effects of scandium heterogeneous distribution on the precipitation behavior of $\mathrm{Al}_{3}(\mathrm{Sc}, \mathrm{Zr})$ in aluminum alloys. Mater Char 174: 110971. DOI: https://doi.org/10.1016/j.matchar.2021.110971 Accessed 27 Sep 2021

18. Liu CY, Zhang B, Ma ZY, Jiang HJ, Zhou WB (2019) Effect of Sc addition, friction stir processing, and T6 treatment on the damping and mechanical properties of 7055 Al alloy. J Alloys Compd 772: 775781 https://doi.org/10.1016/j.jallcom.2018.09.109 Accessed 27 Sep 2021

19. Wang Y, Liu HY, Ma XC, Wu RZ, Sun JF, Hou LG, Zhang JH, Li XL, Zhang ML (2019) Effects of Sc and Zr on microstructure and properties of 1420 aluminum alloy. Mater Charact 154: 241-

247 https://doi.org/10.1016/j.matchar.2019.06.001 Accessed 27 Sep 2021

20. Wang Y, Xiong BQ, Li ZH, Huang SH, Wen K, Li XW, Zhang YA (2019) As-cast microstructure of Al-Zn-Mg-CuZr alloy containing trace amount of Sc. Rare Metals 38: 343-349 https://doi.org/10.1007/s12598-0181136-5 Accessed 27 Sep 2021

21. Belov NA (2010) Phase composition of industrial and promising aluminum alloys. MISiS. Moscow.

22. Yashin VV, Aryshenskiy VYu, Latushkin IA, Tepterev MS (2018) Substantiation of a manufacturing technology of flat rolled products from Al - Mg - Sc based alloys for the aerospace industry. Tsvetnye 
Metally 7 75-82. DOI: 10.17580/tsm.2018.07.12

23. Juri A. Gorbunov (2015) The Role and Prospects of Rare Earth Metals in the Development of PhysicalMechanical Characteristics and Applications of Deformable Aluminum Alloys. Siberian Federal Univ Eng Technol 8(5): 636-645 http://journal.sfu-kras.ru/en/article/19784 Accessed 27 Sep 2021

24. Zakharov VV (2018) Prospects of Creation of Aluminum Alloys Sparingly Alloyed with Scandium. Met Sc Heat Treat (3-4): 172-176. DOI: https://doi.org/10.1007/s11041-018-0256-8 Accessed 27 Sep 2021

25. Bronz AV, Efremov VI, Plotnikov AD, Chernyavskiy AG (2014) Alloy 1570C - material for pressurized structures of advanced reusable vehicles of RSC “Energia”. Kosmicheskaya tekhnika i tekhnologii [Space engineering and technology] 4(7): 62-67.

26. Zakharov VV, Filatov YA, Fisenko IA (2020) Scandium Alloying of Aluminum Alloys. Met Sc Heat Treat 62: 518-523. DOI: https://doi.org/10.1007/s11041-020-00595-0 Accessed 27 Sep 2021

27. Konstantinov IL, Baranov VN, Sidelnikov SB, Kulikov BP, Bezrukikh Al, Frolov VF, Orelkina TA, Voroshilov DS, Yuryev PO, Belokonova IN (2020) Investigation of the structure and properties of cold-rolled strips from experimental alloy 1580 with a reduced scandium content. Int J Adv Manuf Technol 109(1-2): 443450. https://doi.org/10.1007/s00170-020-05681-4 Accessed 27 Sep 2021

28. Dovzhenko IN, Dovzhenko NN, Sidelnikov SB, Konstantinov IL (2017) 3D modelling of the large-capacity ingots of an $\mathrm{Al}$ - Mg system aluminium alloy doped with scandium rolling process. Non-Ferrous Metals 43(2):60-64. http://rudmet.net/media/articles/Article_NFM_02_17_pp.60-64_1.pdf Accessed 27 Sep 2021

29. Xu P, Jiang F, Tang ZQ, Yan N, Jiang JY, Xu X, Peng YY (2019) Coarsening of Al3Sc precipitates in Al-Mg-Sc alloys. J Alloys Compd 781: 209-215 https://doi.org/10.1016/j.jallcom.2018.12.133 Accessed 27 Sep 2021

30. Xu PA, Jiang F, Tong MM, Tang ZQ, Jiang JY, Yan N, Peng YY (2019) Precipitation characteristics and morphological transitions of Al3Sc precipitates. J Alloys Compd 790: 509516 https://doi.org/10.1016/j.jallcom.2019.03.256 Accessed 27 Sep 2021

31. Fernandez V (2017) Rare-earth elements market: A historical and financial perspective. Resources Policy 53: 26-45 https://doi.org/10.1016/j.resourpol.2017.05.010 Accessed 27 Sep 2021

32. Ramasamy DL, Puhakka V, Repo E, Ben Hammouda S, Sillanpää M (2018) Two-stage selective recovery process of scandium from the group of rare earth elements in aqueous systems using activated carbon and silica composites: Dual applications by tailoring the ligand grafting approach. Chem Eng J 341: 351360 https://doi.org/10.1016/j.cej.2018.02.024 Accessed 27 Sep 2021

33. Ge J, Wang X, Guan Q, Li W, Zhu H, Yao M (2016) World rare earths trade network: Patterns, relations and role characteristics. Resources Policy 50: 119-130 https://doi.org/10.1016/j.resourpol.2016.09.002 Accessed 27 Sep 2021

34. Jha R, Dulikravich GS (2020) Solidification and heat treatment simulation for aluminum alloys with scandium addition through CALPHAD approach. Comput Mater Sci 182: 109749 https://doi.org/10.1016/j.commatsci.2020.109749 Accessed 27 Sep 2021

35. Xu C, Xiao WL, Zheng RX, Hanada S, Yamagata H, Ma CL (2015) The synergic effects of Sc and Zr on the microstructure and mechanical properties of Al-Si-Mg alloy. Mater Des 88: 485492 https://doi.org/10.1016/j.matdes.2015.09.045 Accessed 27 Sep 2021 
36. Sidelnikov SB, Yakivyuk OV, Baranov VN, Konstantinov IL, Dovzhenko IN, Lopatina ES, Voroshilov DS, Samchuk AP, Frolov VA (2019) Computer simulation, analysis of force and temperature-speed parameters of the process of combined machining of Al-Mg-Sc alloys. IOP Conf Ser: Mater Sci Eng 544:

012018. https://doi.org/10.1088/1757-899X/544/1/012018 Accessed 27 Sep 2021

37. Mann VK, Sidelnikov SB, Konstantinov IL, Baranov VN, Dovzhenko IN, Voroshilov DS, Lopatina ES, Yakivyuk OV, Belokonova IN (2019) Modeling and investigation of the process of hot rolling of large-sized ingots from aluminum alloy of the AIMg system, economically alloyed by scandium. Mater Sci Forum943:5865. https://doi.org/10.4028/www.scientific.net/MSF.943.58 Accessed 27 Sep 2021

38. Konstantinov IL, Baranov VN, Sidelnikov SB, Arnautov AD, Voroshilov DS, Dovzenko NN, Zenkin EY, Bezrukikh Al, Dovzenko IN, Yuryev PO (2021) Investigation of cold rolling modes of 1580 alloy by the method of computer simulation. Int J Adv Manuf Technol 112(7):19651972. https://doi.org/10.1007/ s00170-020-06570-6 Accessed 27 Sep 2021

39. Baranov VN, Zenkin EY, Konstantinov IL, Sidelnikov SB (2019) The research of the cold rolling modes for plates of aluminum alloy sparingly doped with scandium. Non-ferrous Metals 2:4852. https://doi.org/10.17580/nfm.2019.02.08 Accessed 27 Sep 2021

40. Dovzhenko NN, Rushchits SV, Dovzhenko IN, Yurev PO (2019) Understanding the behaviour of aluminium alloy P-1580 sparingly doped with scandium under hot deformation. Tsvetnye Metally 9: 8086. https://doi.org/10.17580/tsm.2019.09.13 Accessed 27 Sep 2021

41. Baranov VN, Sidelnikov SB, Zenkin EY, Bezrukikh Al, Konstantinov IL, Sokolov RE, Voroshilov DS, Belokonova IN, Yakivyuk OV (2017) Study of the mechanical properties of semifinished products from aluminum-scandium alloy. Bull Tula State Univ 11(1):147-153

42. Baranov VN, Sidelnikov SB, Zenkin EY, Voroshilov DS (2018) Development of fabrication modes of deformed semifinished products from the experimental scandium-containing aluminum alloy and investigation into their mechanical properties. Russ J NonFerrous Metals 59(1):6266 https://doi.org/10.3103/S1067821218010042 Accessed 27 Sep 2021

43. Baranov V, Sidelnikov S, Voroshilov D, Yakivyuk O, Konstantinov I, Sokolov R, Belokonova I, Zenkin E, Frolov $\mathrm{V}$ (2018) Study of strength properties of semi-finished products from economically alloyed high-strength aluminium-scandium alloys for application in automobile transport and shipbuilding. Open Eng 8(1): 6976. DOI: https://doi.org/10.1515/eng-2018-0005 Accessed 27 Sep 2021

44. Dovzhenko NN, Rushchits SV, Dovzhenko IN, Sidelnikov SB, Voroshilov DS, Demchenko Al, Baranov VN, Bezrukikh Al, Yuryev PO (2021) Deformation behavior during hot processing of the alloy of the Al-Mg system economically doped with scandium. Int J Adv Manuf Technol 115(7-8): 2571-2579, DOI: https://doi.org/10.1007/s00170-021-07338-2 Accessed 27 Sep 2021

45. Baranov VN, Sidelnikov SB, Bezrukikh Al, Zenkin EY (2017) Research of rolling regimes and mechanical properties of coldrolled, annealed and welded semi-finished products from experimental alloys of $\mathrm{Al}-\mathrm{Mg}$ system, economically alloyed by scandium. Tsvetnye Metally 9:91-

96. https://doi.org/10.17580/tsm.2017. 09.13 Accessed 27 Sep 2021

46. Konstantinov IL, Baranov VN, Sidelnikov SB, Zenkin EY, Yuryev PO, Belokonova IN (2020) Influence of rolling and annealing modes on properties of sheet semifinished products made of wrought aluminum alloy 1580. Russ J Non-Ferrous Metals 61: 641-645. https://doi.org/10.3103/S1067821220060115 Accessed 27 Sep 2021 
47. Yuryev PO, Baranov VN, Orelkina TA, Bezrukikh Al, Voroshilov DS, Murashkin MYu, Partyko EG, Konstantinov IL, Yanov VV, Stepanenko NA (2021) Investigation the structure in cast and deformed states of aluminum alloy, economically alloyed with scandium and zirconium. Int J Adv Manuf Technol 115(1): 263-274, DOI: https://doi.org/10.1007/s00170-021-07206-z Accessed 27 Sep 2021

48. Baranov VN, Sidelnikov SB, Frolov VF, Zenkin EYu, Orelkina TA, Konstantinov IL, Voroshilov DS, Yakivyuk OV, Belokonova IN (2018) Investigation of mechanical properties of cold-rolled, annealed and welded semifinished products from the test alloys of Al-Mg system, economically alloyed with scandium. IOP Conf Ser: Mater Sci Eng 411: 012015. https://doi.org/10.1088/1757-899X/411/1/012015 Accessed 27 Sep 2021

49. Dovzhenko NN, Demchenko Al, Bezrukikh AA, Dovzhenko IN, Baranov VN, Orelkina TA, Dementeva IS, Voroshilov DS, Gaevskiy VN, Lopatina ES (2021) Mechanical properties and microstructure of multi-pass butt weld of plates made of Al-Mg-Zr alloy sparingly doped with scandium. Int J Adv Manuf Technol 113:785-805. https://doi.org/10.1007/s00170-021-06665-8 Accessed 27 Sep 2021

50. Baranov VN, Sidelnikov SB, Zenkin EY, Konstantinov IL, Lopatina ES, Yakivyuk OV, Voroshilov DS, Belokonova IN, Frolov VA (2019) Study on the influence of heat treatment modes on mechanical and corrosion properties of rolled sheet products from a new aluminum alloy, economically alloyed with scandium. Vestnik of Nosov Magnitogorsk State Techn Univ 17(1):76-81. https://doi.org/10.18503/19952732-2019-17-1-76-81 Accessed 27 Sep 2021

\section{Figures}




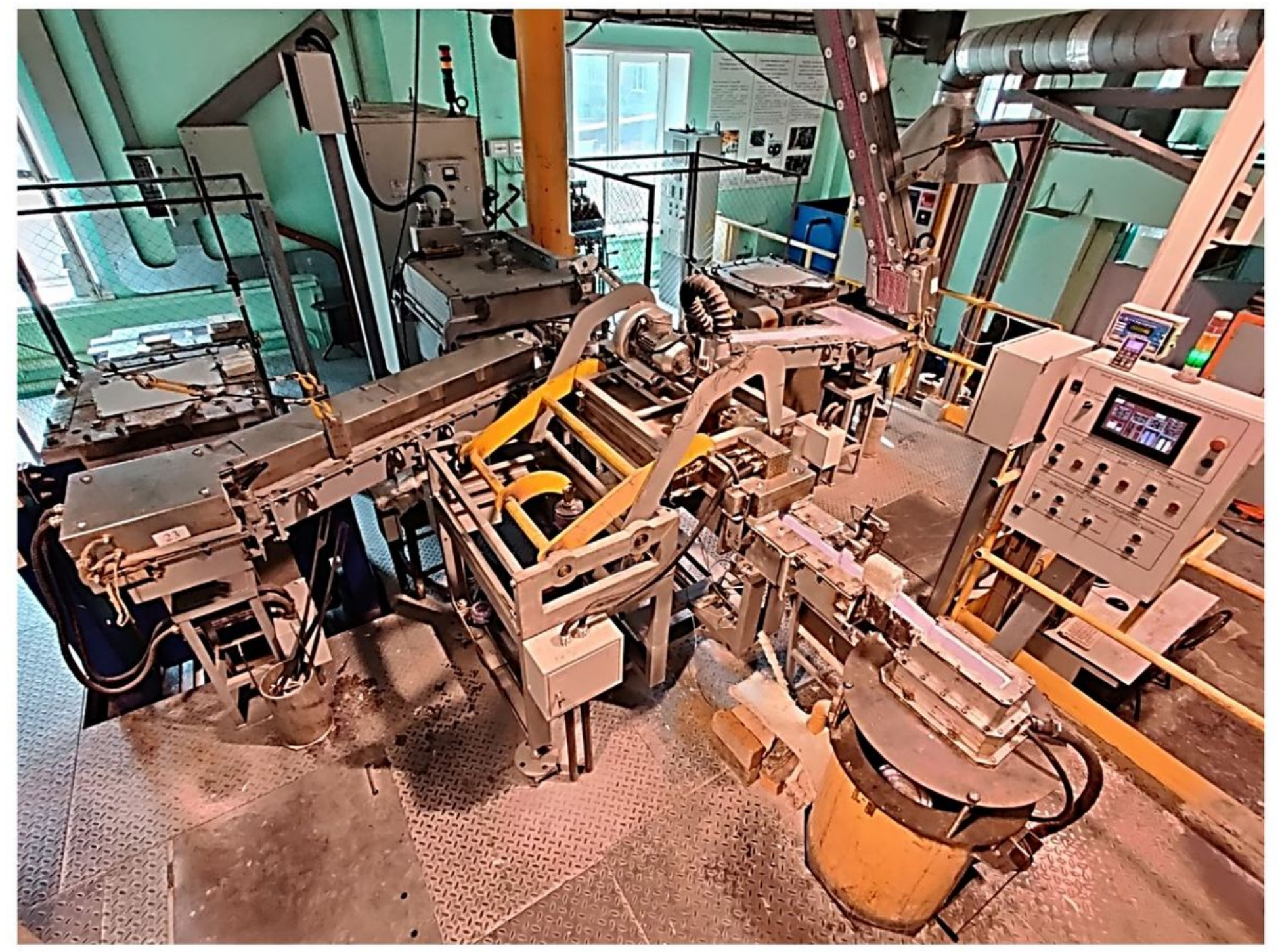

Figure 1

General view of the SCCU 


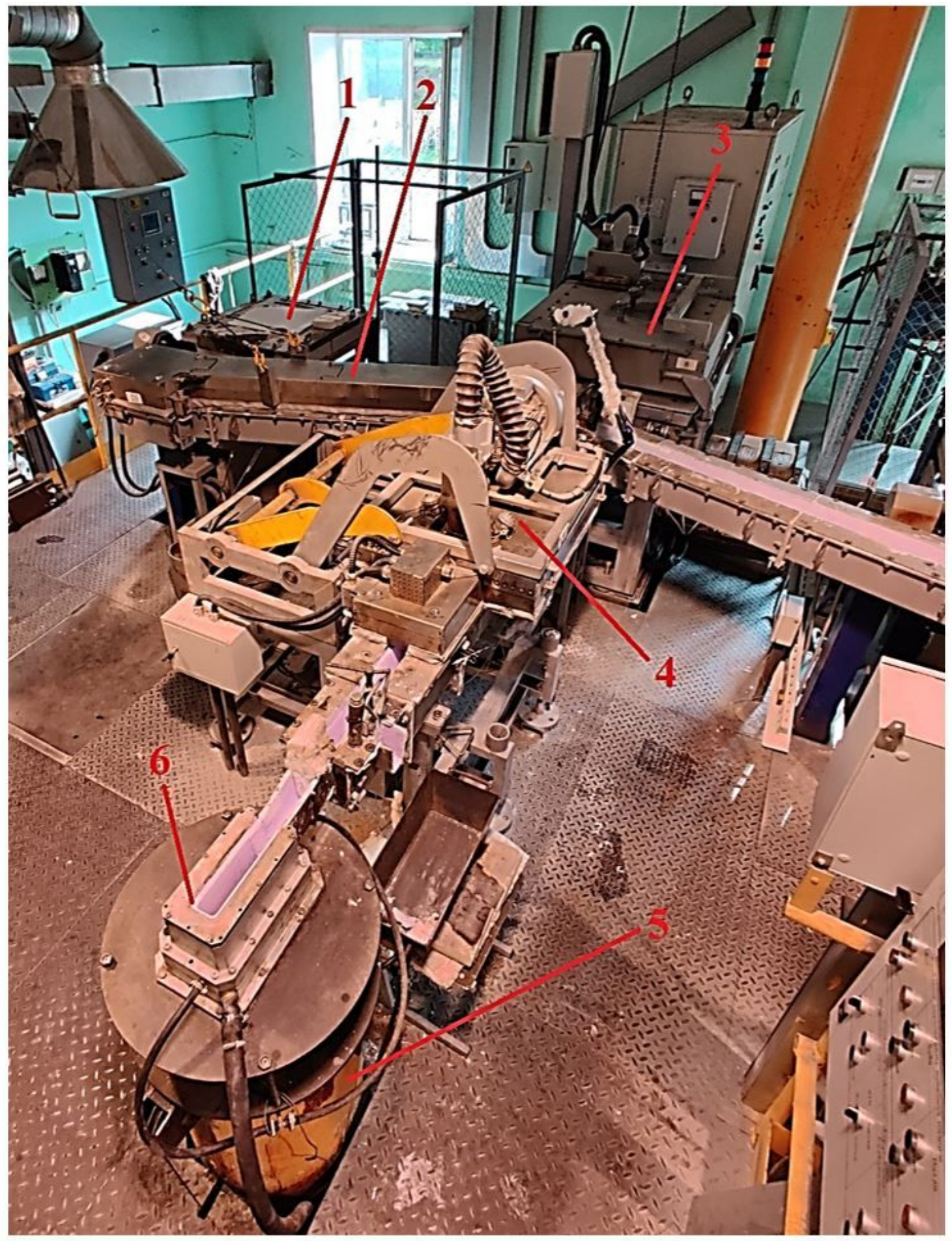

Figure 2

The main units of the SCCU: 1 - induction crucible furnaces; 2 - metal track with heated lid; 3 - rotary electrically heated mixer; 4 - filtration section; 5 - vertical casting machine; 6 - mold 


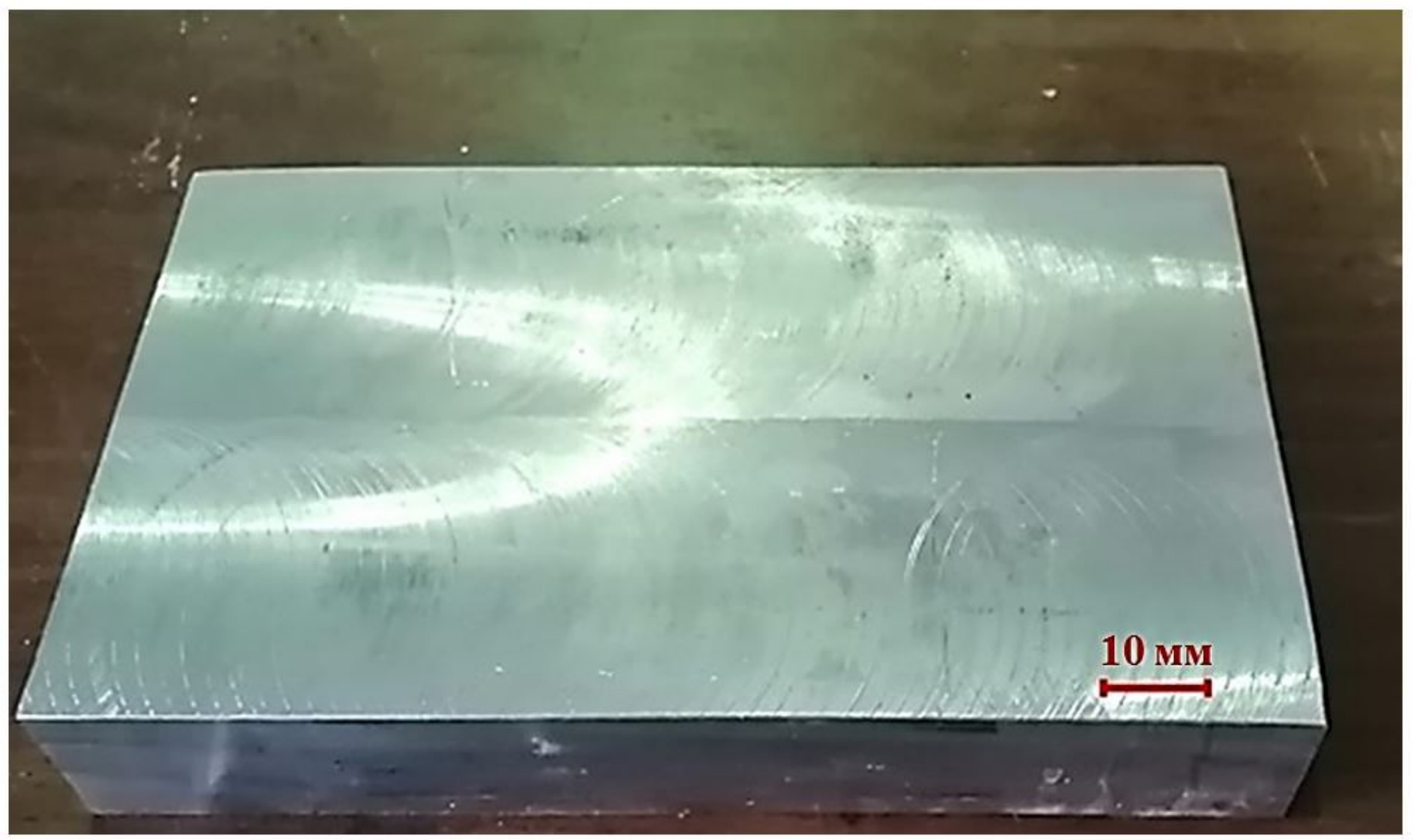

Figure 3

Ingot for rolling from alloy 1580 


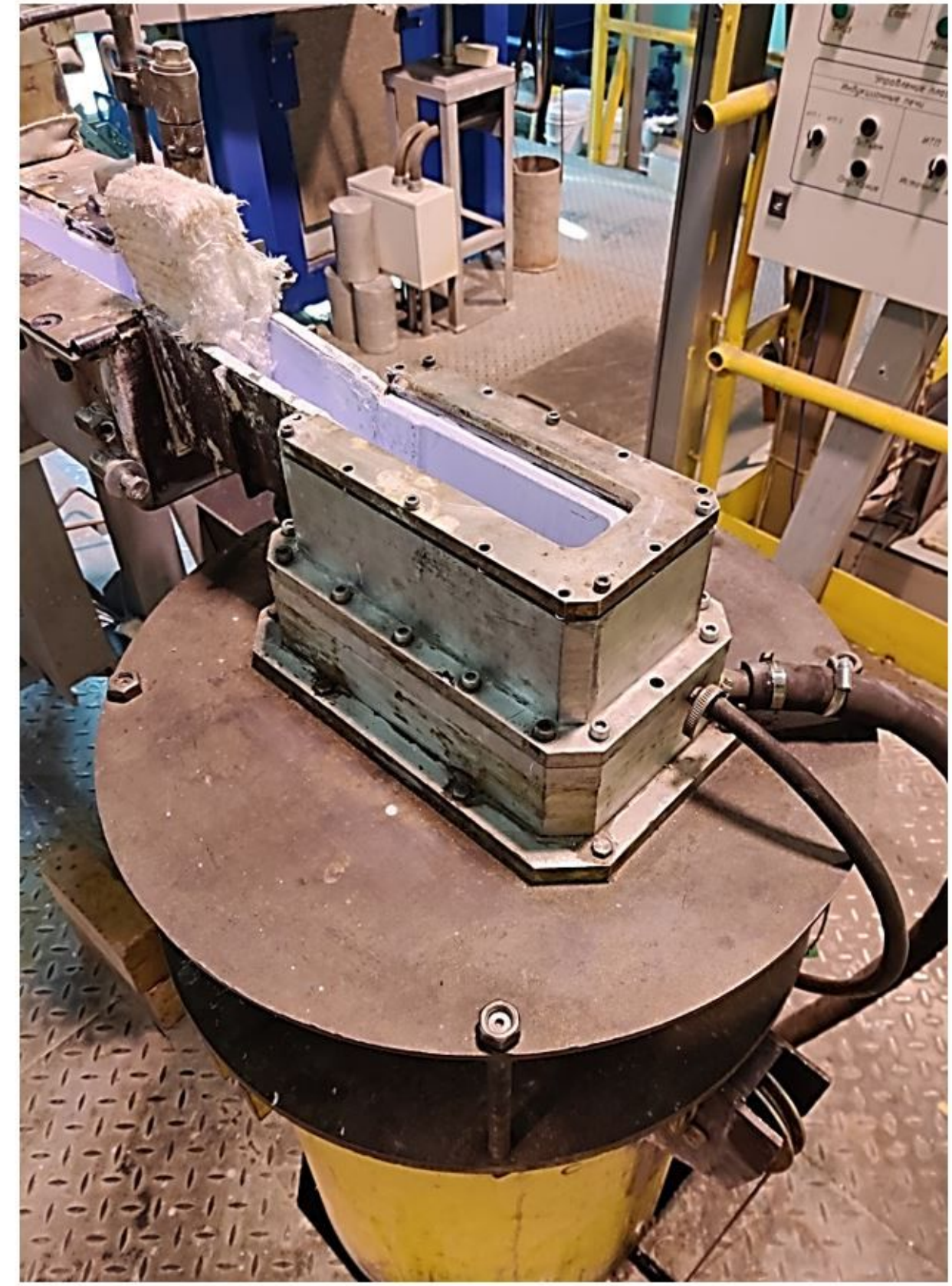

$a$

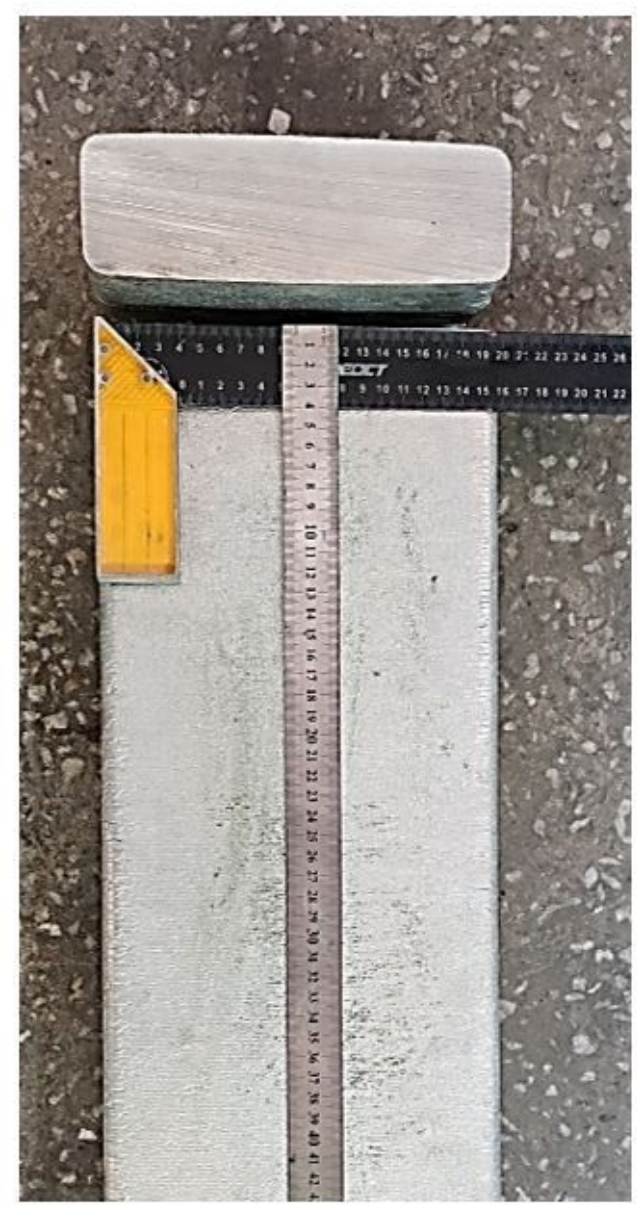

$b$

\section{Figure 4}

Casting equipment of the Hot-top type for physical modeling (a) and an ingot made of alloy 1580 (b) obtained by casting at the SCCU (the cross section of the ingot) 


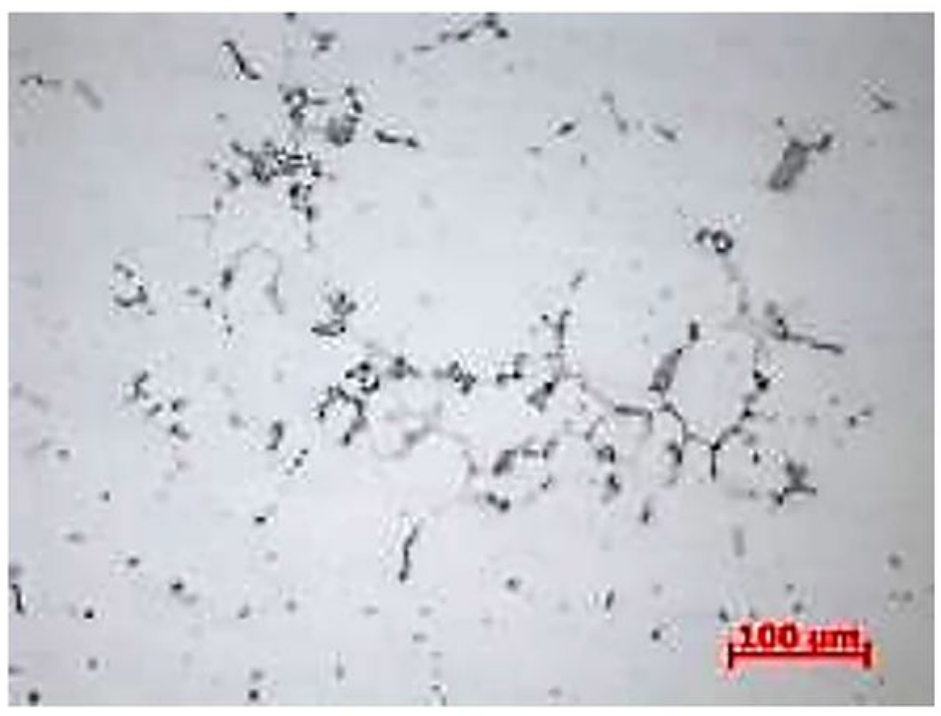

$a$

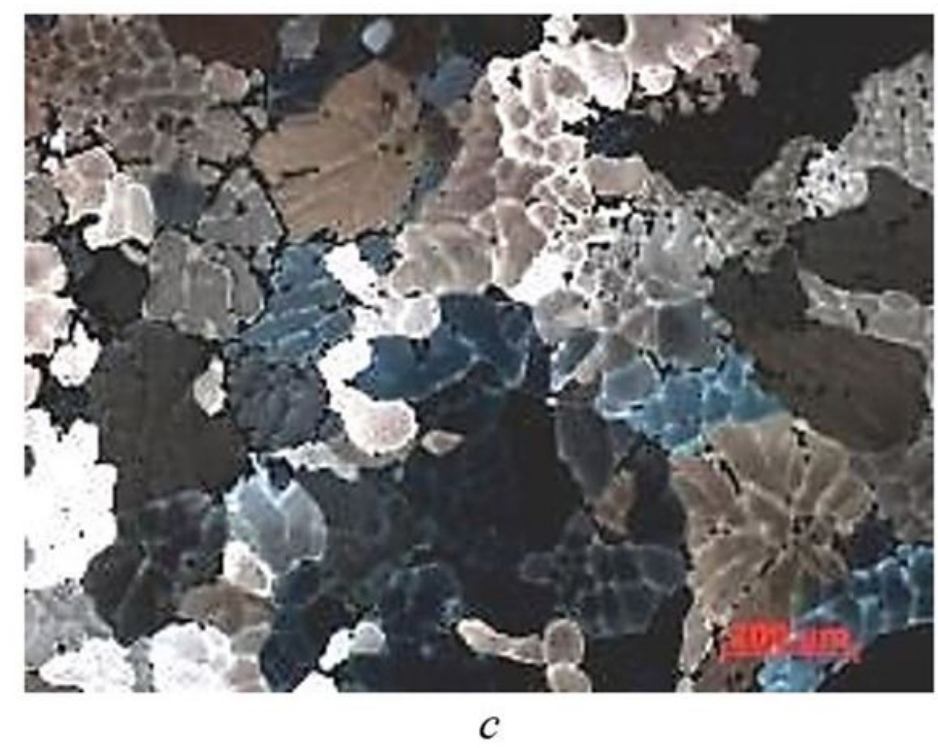

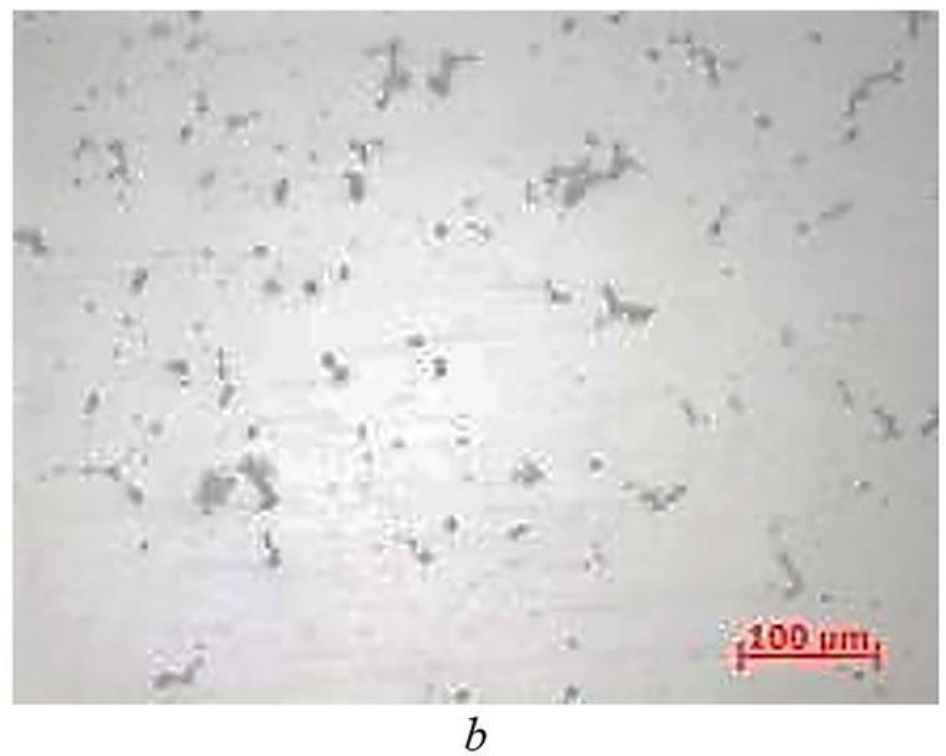

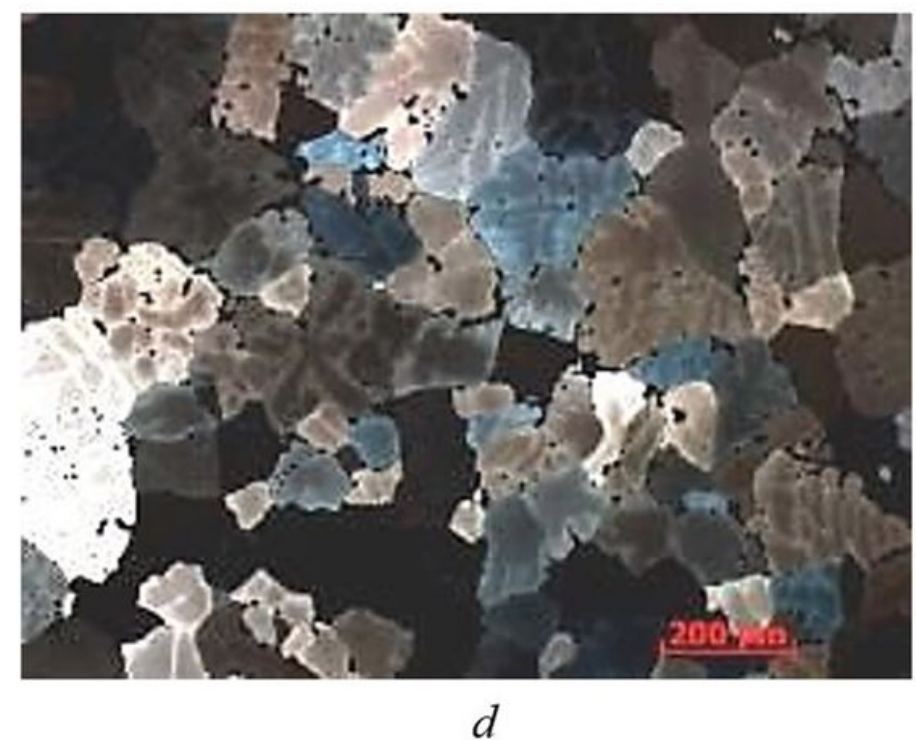

Figure 5

Microstructure of alloy 1580 with a scandium content of $0.055 \%$ (wt.) in the cast $(a, c)$ and annealed (b, d) state: a, b - brightfield image; c, d - polarized light image 

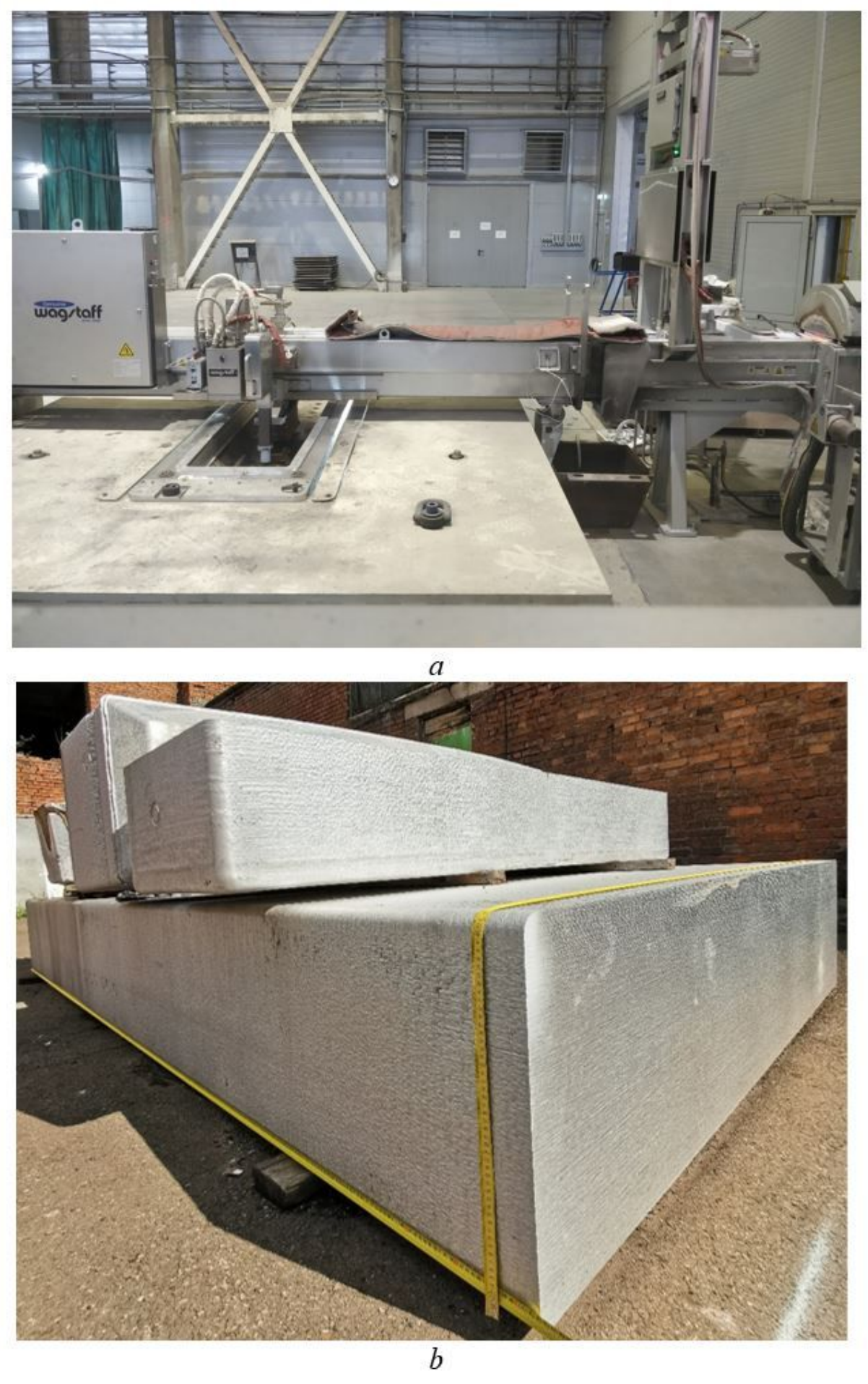

Figure 6

Industrial casting equipment WaggStaff (a), large-sized flat ingot (slab) from alloy 1580 with cut-off bottom and runner parts (b) 